\title{
ANALISA HUBUNGAN ANTARA PRODUK DOMESTIK BRUTO DAN EKSPOR INDONESIA (UJI KAUSALITAS GRANGER)
}

\author{
Debora Silvia Hutagalung ${ }^{1)}$, Junaidi ${ }^{2}$ \\ ${ }^{1)}$ Program Studi Manajemen, Sekolah Tinggi Akuntansi Dan Manajemen Indonesia \\ email. deborahutagalung9@gmail.com \\ ${ }^{2}$ Program Studi Akuntansi, Sekolah Tinggi Akuntansi Dan Manajemen Indonesia \\ Email: junaidisiahaan2303@gmail.com
}

\begin{abstract}
This study entitled "Analysis of The Relationship Between Gross Domestic Product and Indonesian Exports (Granger causality test)". This research was conducted because of the dualism of the theory between the two variables. In macroeconomic theory, the relationship between Gross Domestic Product is one of the similarities, because exports contribute to Gross Domestic Products on the demand side, while neoclassical trade theory emphasizes causality related to household production and assistance for exports. The purpose of this study is to determine the relationship between Gross Domestic Product and exports. This study uses several analytical methods: Unit Root Test, Cointegration Test, Granger Causality Test using the E-views program7 and using Quarterly data. The results of the estimation of this study are the estimation of the relationship in GDP and exports, or in other words the Gross Domestic Product affects Indonesia's exports. This is concluded based on the estimation results that can be seen from the statistical $F$ value that is greater than the f-table (8.958205> 3.841466) on the Null hypothesis. GDP is not an Export Granger with a 95\% confidence level. This means, GDP affects exports When GDP can affect the level of exports in the intervals of 2000 to 2012.
\end{abstract}

Keywords: Gross Domestic Product(GDP), Exports, Granger Causality Test

\section{PENDAhULUAN}

Produk Domestik Bruto (PDB) yang meningkat merupakan impian setiap negara. Masalah bagaimana sebuah negara dapat meningkatkan pendapatan domestik bruto-nya merupakan salah satu pertanyaan fundamental di bidang perkonomian negara tersebut. Peningkatan Produk Domestik Bruto (PDB) mencerminkan kondisi suatu negara apakah negara tersebut mengalami kemajuan di bidang perekonomian atau sebaliknya[1].

Dalam ekonomi makro, pengertian PDB terbagi menjadi dua, yaitu : seluruh pengeluaran untuk barang jadi dan jasa yang diproduksi dalam negeri atau seluruh pendapatan yang dihasilkan oleh seluruh pemilik faktor produksi dalam negeri. Salah satu komponen yang memberikan kontribusi terhadap Produk Domestik Bruto(PDB) adalah total ekspor. Dalam teori ekonomi makro (macroeconomic theory), hubungan antara ekspor dengan pendapatan nasional merupakan suatu persamaan identitas karena ekspor merupakan bagian dari tingkat pendapatan nasional $(\mathrm{PDB}=\mathrm{C}+\mathrm{I}+\mathrm{G}+\mathrm{X}-\mathrm{M})$.

Tabel 1.1 menunjukkan proporsi ekspor terhadap PDB tahun 2013-2017. Ekspor bernilai positif setiap tahunnya meskipun bersifat fluktuatif. Pada tahun 2013 ekspor barang dan jasa Indonesia mencapai $25 \%$ dan impor $24 \%$, hal ini berarti net-ekspor 1\%, tahun 2014 net ekspor masih surplus sebesar $0,7 \%$ meskipun proporsi tahun 2014 lebih rendah dibandingkan dengan tahun sebelumnya.

Neraca perdagangan dengan surplus tertinggi terjadi pada tahun 2017 sebesar 1,9\% ( NX /Net Ekspor $=$ Ekspor-Impor) dan pada tahun 2015 dan 2016 net-ekspor memiliki proporsi 1,6\% dari PDB sisi permintaan. Nilai Net Ekspor diharapkan meningkat positif setiap tahunnya dengan cara meningkatkan ekspor atau dengan menekan impor. Ekspor memberikan kontribusi 
DOI 10.37600/ekbi.v3i2.191

yang nyata terhadap peningkatan Produk Domestik Bruto.

Tabel 1. Proporsi Komponen (\%) Terhadap PDB Indonesia Menurut Pengunaan

Tahun 2013-2017 Atas Harga Konstan 2010

\begin{tabular}{lrrrrr}
\hline \multicolumn{1}{c}{ Uraian } & \multicolumn{5}{c}{ Tahun } \\
& $\mathbf{2 0 1 3}$ & $\mathbf{2 0 1 4}$ & $\mathbf{2 0 1 5}$ & $\mathbf{2 0 1 6}$ & $\mathbf{2 0 1 7}$ \\
\hline Konsumsi RT & 54.6 & 54.8 & 54.7 & 54.9 & 54.8 \\
Konsumsi LNPRT & 1.09 & 1.17 & 1.11 & 1.13 & 1.15 \\
Konsumsi Pemerintah & 8.99 & 8.68 & 8.69 & 8.29 & 8.06 \\
PMTB & 32.8 & 32.7 & 32.6 & 32.6 & 32.9 \\
Perubahan Inventori & 1.54 & 1.93 & 1.26 & 1.43 & 1.18 \\
Ekspor Barang dan Jasa & 25 & 24.1 & 22.5 & 21.1 & 21.9 \\
Impor Barang dan Jasa & 24 & 23.4 & 20.9 & 19.5 & 20 \\
Total PDB & 100 & 100 & 100 & 100 & 100 \\
\hline Sum & & & &
\end{tabular}

Sumber: Data Diolah, BPS, 2020

Ekspor merupakan sumber yang penting bagi valuta asing, apabila terjadi peningkatan ekspor maka akan mengurangi tekanan pada neraca pembayaran dan menghasilkan kesempatan kerja yang sangat dibutuhkan . Ekspor dapat membantu negara untuk berintegrasi dalam ekonomi dunia dan membantu mengurangi dampak dari guncangan eksternal pada perekonomian domestik. Ekspor memungkinkan produksi dalam negeri mencapai tingkat tinggi skala ekonomi dan menjadikan sektor ini sebagai mesin penggerak pertumbuhan ekonomi [1]-[3]. Pengalaman ekonomi Asia Timur memberikan contoh yang baik tentang pentingnya ekspor terhadap pertumbuhan ekonomi dan pembangunan, dan ini menekankan peran ekspor sebagai mesin pertumbuhan ekonomi. Ekspor akan secara langsung memberi kenaikan penerimaan dalam pendapatan suatu negara. Terjadinya kenaikan penerimaan pendapatan suatu negara akan mengakibatkan terjadinya kenaikan tingkat PDB. Dengan kata lain ekspor akan menyebabkan pertumbuhan ekonomi [1], [3]-[6].

Namun demikian yang menjadi pertanyaan adalah apakah ekspor memberikan pengaruh dan kontribusi bagi kenaikan PDB atau apakah PDB yang mampu mempengaruhi kenaikan ekspor di Indonesia? Dari latar belakang dan permasalahan yang ada, maka tujuan dari penelitian ini adalah untuk mengetahui bagaimana arah hubungan antara Produk Domestik Bruto dan Ekspor di Indonesia

\subsection{Konsep Dualitas Teori Hubungan Antara PDB dan Ekspor}

Dalam rumus identitas, ekspor merupakan variabel bebas yang mempengaruhi Produk Domestik Bruto. Dimana PDB merupakan kumulatif antara konsumsi rumah tangga, investasi, belanja pemerintah dan ekspor bersih ( ekspor-impor ).

$$
\mathbf{Y}=\mathbf{C}+\mathbf{I}+\mathbf{G}+(\mathbf{X}-\mathbf{M})
$$

Jadi hubungan antara ekspor dan PDB dapat di gambarkan sebagai berikut :

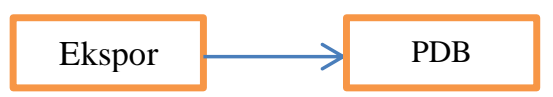

Gambar 1. Hubungan Ekspor Terhadap PDB

Sementara itu dalam teori lain dikatakan bahwa peningkatan Produk Domestik Bruto (PDB) akan menaikkan tingkat ekspor. Beberapa penelitian menyatakan bahwa 
adalah masuk akal bahwa uji kausalitas bisa menolak hipotesis exports-led growth. Akumulasi modal manusia dan fisik serta perubahan tekhnologi terbatas hanya terjadi di sedikit industry. Karena pertumbuhan yang tidak seimbang ini, hampir mustahil permintaan untuk produk industri yang mengalami boom akan bertambah secepat produksi. Akibatnya, industri yang mengalami boom ini mengalihkan upaya ke pasar internasional meskipun tanpa diberi insentif. Dalam kasus demikian, pertumbuhan ekonomi domestik yang tinggi mengakibatkan peningkatan ekspor.

Peningkatan PDB akan membuat ekonomi semakin membaik, industri juga akan mengalami peningkatan sehingga akan mendorong ekspor yang lebih dibanding tahun sebelumnya. Mekanisme yang lain dimana PDB mempengaruhi Ekspor adalah meningkatnya PDB suatu negara akan meningkatkan daya beli konsumen sehingga secara tidak langsung menaikkan nilai tukar (USD/Rupiah) atau dengan kata lain rupiah mengalami depresiasi sehingga akan mendorong ekspor.

Jadi hubungan antara Ekspor dan PDB dapat digambarkan sebagai berikut :

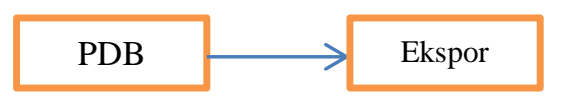

Gambar 2. Hubungan PDB Terhadap Ekspr

Ada banyak penelitian tentang ekspor dan pertumbuhan ekonomi. Penelitian didasarkan oleh keingintahuan apakah suatu negara harus meningkatkan ekspor untuk meningkatkan pertumbuhan ekonomi atau harus merangsang pertumbuhan ekonomi terlebih dahulu untuk meningkatkan ekspor. Hubungan pertumbuhan ekonomi mempengaruhi ekspor. Pertumbuhan mempengaruhi ekspor berangkat melalui mekanisme efisiensi yang disebabkan oleh peningkatan tingkat ketrampilan tenaga kerja dan kemajuan tekhnologi [7]-[9].

Perkembangan ekspor dan bebasnya keluar masuk modal merupakan penyebab utama pertumbuhan ekonomi. Sebagai contoh, perusahaan dapat mengambil keuntungan dan alokasi sumber daya yang lebih efisien, skala ekonomi kreatif dan inovasi yang disebabkan oleh kompetisi asing. [10], [11]. Selain itu ekpsor dapat menyebabkan lebih banyak impor barang setengah jadi yang menyebabkan meningkatnya akumulasi modal dan pertumbuhan output.

Penelitian ini menyatakan bahwa sampai saat ini tidak ada kesepakatan antara arah kausal dari perdagangan bebas (ekspor) dan pertumbuhan ekonomi hal ini menunjukkan adanya pola yang berbeda. Beberapa model yang dikemukakan oleh Grossman dan Helpman, Rivera Batiz dan Romer menyatakan bahwa perdagangan internasional mampu meningkatkan pertumbuhan ekonomi [8].

ekspor mempengaruhi pertumbuhan ekonomi melalui mekanisme:

1. Peningkatan ekspor akan mempengaruhi pertumbuhan ekonomi dengan adanya multiplier effect dari perdagangan luar negeri sehingga terjadi ekspansi produksi dan tenaga kerja.

2. Pertumbuhan ekspor juga akan memungkinkan peningkatan impor barang modal yang akan meningkatkan potensi produksi ekonomi.

3. Kompetisi ekspor di pasar bebas akan menyebabkan percepatan skala ekonomi dan kemajuan tekhnologi dalam produksi.

Bhangawati dan Krugman menyatakan untuk arah kausalitas pertumbuhan ekonomi menyebabkan ekpsor distimulasi oleh peningkatan kemampuan tenaga kerja dan tekhnologi domestik. Teori perdagangan neoklasik menekankan kausalitas yang berjalan dari produksi rumah tangga dan produktivitas untuk pasokan ekspor.

Penelitian ini mencoba untuk menemukan jawaban bagaimana hubungan arah antara Pendapatan Domestik Bruto dan ekspor. Jadi kerangka pemikiran dapat digambarkan sebagai berikut

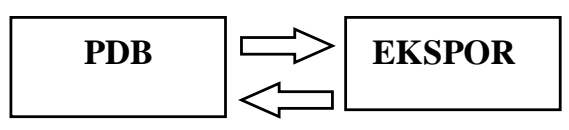




\section{Gambar 3. Kerangka Pemikiran}

Hipotesis pada penelitian ini adalah PDB mempengaruhi Ekspor dimana perubahan PDB akan mempengaruhi nilai ekspor total.

\section{METODE PENELITIAN}

\subsection{Ruang Lingkup}

Ruang lingkup penelitian adalah mencakup bagaimana hubungan antara Produk Domestik Bruto dan Ekspor di Indonesia selama periode tahun 2000-2012.

\subsection{Jenis dan Sumber Data}

Jenis data yang digunakan adalah data dalam bentuk time series yang dicatat dari Biro Pusat Statistik (BPS) pada kurun waktu tahun 2000 sampai 2012 (13 tahun) menggunakan data triwulan.

\subsection{Metode dan Teknik Pengumpulan Data}

Dalam penyusunan penelitiana ini penulis menggunakan penelitian kepustakaan (library research), yang dilakukan melalui:

a) bahan-bahan kepustakaan berupa tulisantulisan ilmiah,

b)laporan-laporan penelitian ilmiah yang berhubungan dengan topik yang diteliti.

Teknik pengumpulan data yang dipergunakan adalah melakukan pencatatan langsung berupa time series yaitu tahun 2000 sampai 2012 (sampel data 13 tahun menggunakan data triwulan) yang diperoleh dari laporan tahunan yang dikeluarkan oleh Badan Pusat Statistik.

\subsection{Model Analisis Data}

Model yang digunakan dalam penelitian ini adalah sebagai berikut

$$
P D B t=\sum_{i=1}^{m} \alpha I P D B t-1+\sum_{\substack{j=1 \\ \text { Persamaan } 1}}^{n} b j E k s t-j+\mu 1-\mathrm{t}
$$

$$
\text { Ekspor }=\sum_{\mathrm{i}=1}^{\mathrm{r}} \lambda I P D B t-1+\sum_{\mathrm{j}=1}^{\mathrm{m}} \gamma j \text { Eersamant } 2 \text { Ekt }-j+\mu 2 \mathrm{t}
$$

Dimana:

a. PDBt $=$ PDB yaitu semua komponen permintaan akhir yang terdiri dari : pengeluaran konsumsi rumah tangga dan lembaga swasta nirlaba, pengeluaran konsumsi pemerintah, pembentukan modal tetap domestic bruto atau sering disebut investasi, perubahan inventori dan ekspor neto, yaitu ekspor dikrangi impor. PDB merupakan seluruh konsumsi pemerintah dan masyarakat, pengeluaran pemerintah, investasi dan ekspor dikurangi impor Indonesia yang dinyatakan dalam nilai juta US\$

b. Eksrt = Ekspor adalah arus keluar sejumlah barang dan jasa dari Indonesia ke pasar internasional berdasarkan nilai FOB (Free On Board) dan dinyatakan dalam satuan mata uang US\$

c. $\mu 1 \mathrm{t}$ dan $\mu 2 \mathrm{t}$ adalah error terms yang diasumsikan tidak mengandung korelasi serial dan $\mathrm{m}=\mathrm{n}$

\subsection{Teknik Analisis Data}

Pengolahan data dimulai dengan uji Stationaritas, uji Kointegrasi, dan uji Kausalitas Granger

\section{HASIL DAN PEMBAHASAN}

\subsection{Uji Akar Unit (Unit Root Test)}

Dalam analisis runtun waktu, asumsi stasioneritas dari data merupakan sifat yang penting. Uji stasioner dalam penelitian ini menggunakan Uji Akar Unit dengan menggunakan metode Augmented Dickey Fuller (ADF). Pengujian ini dilakukan untuk menghindari model yang lancung atau tidak efisien. Data yang digunakan dalam Uji ADF ini dari selang waktu tahun 2000 triwulan I sampai tahun 2012 triwulan ke-IV, berikut ini hasil uji ADF 
Tabel 2. Uji Akar Unit Ekspor

\begin{tabular}{lcccc}
\hline Variabel & ADF & Critical Value & Probability & Derajat Integrasi \\
Ekspor & $-7,183125$ & -4.152511 & 0.0000 & I(1) \\
\hline
\end{tabular}

Dari tabel diatas, dapat dilihat hasil pengujian unit akar tehadap variabel ekspor stasioner pada derajat integrasi 1 atau I (1). Artinya variabel ekspor yang digunakan dalam penelitian ini stasioner pada 1st Difference. Hal ini dapat dilihat berdasarkan angka ADF statistic yang diperoleh pada data ekspor sebesar -7,183 125, sedangkan nilai kritis untuk tingkat signifikansi $1 \%$ sebesar -4.152511 . Hasil ini menunjukkan nilai ADF statistic yang lebih besar dari nilai kritisnya (nilai kritis tidak lebih negative). Dengan demikian dapat disimpulkan bahwa data ekspor telah stasioner.

Tabel 3. Uji Akar Unit PDB

\begin{tabular}{lcccc}
\hline Variabel & ADF & Critical Value & Probability & Derajat Integrasi \\
PDB & -8.54693 & $-4,152511$ & 0.0000 & I (1) \\
\hline
\end{tabular}

Pada tabel diatas dapat dilihat hasil pengujian akar unit terhadap variabel PDB. PDB stasioner pada derajat integrasi I atau I (1). Artinya variabel PDB yang digunakan dalam penelitian ini stasioner pada 1st Difference dengan nilai ADF sebesar -8.54693. Hasil ini menunjukkan nilai ADF statistik yang lebih besar dari nilai kritisnya (nilai kritis tidak lebih negative). Dengan demikian dapat disimpulkan bahwa data PDB telah stasioner.

\subsection{Uji Kointegrasi}

Setelah dilakukan uji unit akar pada data ekspor dan PDB dan hasilnya adalah data stasioner pada 1st Difference, maka selanjutnya dilakukan uji kointegrasi untuk mengetahui apakah terdapat hubungan jangka panjang antara kedua variabel tersebut. Uji ini menggunakan Johansen test untuk mengetahui hubungan keseimbangan jangka panjang antara ekspor dan Pendapatan Domestik Bruto (PDB).

Tabel 3. Uji Kointegrasi

\begin{tabular}{ccccc}
\hline Hypothesized & Eigenvalue & $\begin{array}{c}\text { Trace } \\
\text { Statistic }\end{array}$ & $\begin{array}{c}0.05 \\
\text { Critical Value }\end{array}$ & \multirow{2}{*}{ Prob ${ }^{* *}$} \\
No. Of Ce (s) & & 37.42216 & 15.494471 & 0.0000 \\
None $*$ & 0.434067 & 8.958205 & 3.841466 & 0.0028 \\
\hline At most $1 *$ & 0.164031 & & & \\
\hline
\end{tabular}

Dari hasil uji kointegrasi diatas dapat dilihat nilai trace statistic lebih besar dari nilai kritis pada $\alpha 5 \%$. Hal ini berarti bahwa semua variabel yang ada memiliki hubungan jangka panjang dengan nilai pada none (terdapat keseimbangan jangka panjang satu arah) 37.42216 >
15.494471 dan at most (terdapat keseimbangan jangka panjang dua arah) $8.958205>3.841466$. Dengan demikian dapat ditarik kesimpulan adanya keseimbangan jangka panjang antara Pendapatan Domestik Bruto (PDB) dan Ekspor di Indonesia. 


\subsection{Uji Kausalitas Granger}

Uji kausalitas Granger digunakan untuk melihat hubungan kausalitas antara variabel PDB dan Ekspor Indonesia. Melalui uji ini dapat dilihat apakah kedua variabel tersebut memiliki hubungan yang saling memengaruhi (hubungan dua arah), memiliki hubungan searah atau sama sekali tidak memiliki hubungan (tidak saling memengaruhi). Hasil dari pengujian kausalitas Granger dapat dilihat pada tabel dibawah ini:

Tabel 4. Uji Kausalitas Granger

\begin{tabular}{crrr}
\hline Null Hypothesis & Obs & F-Statistic & Probability \\
\hline GDP does not Granger Cause EXPORT & 50 & 5.33078 & 0.00838 \\
EXPORT does not Granger Cause GDP & & 1.35303 & 0.26877 \\
\hline
\end{tabular}

Berdasarkan hasil uji kausalitas Granger di atas, untuk variabel Pendapatan Domestik Bruto (PDB) dan ekspor memliki hubungan satu arah hal ini dapat dilihat dari nilai F-statistic yang lebih besar dari nilai F-tabel yang bernilai 4.03 dan nilai probability lebih kecil dari 0.005 yaitu sebesar 0.0038 ini berarti Null Hypotesis : GDP does not Granger Cause Export ditolak artinya GDP atau PDB memengaruhi Ekspor di Indonesia namun tidak dengan kebalikannya karena Nilai F-statistic pada Null Hypotesis Export does not Granger Cause GDP lebih kecil dari F-tabel dan nilai probability nya lebih besar dari $\alpha 5 \%$.

\subsection{Pengaruh PDB Terhadap Ekspor}

Setelah melakukan estimasi dengan uji kausalitas Granger didapat hasil bahwa Pendapatan Domestik Bruto mempengaruhi Ekspor. Peningkatan Produk Domestik Bruto berarti terjadi peningkatan pendapatan terhadap pendapatan perkapita maupun pendapatan pelaku usaha secara signifikan. Dengan meningkatnya pendapatan maka kemampuan untuk menabung atau berinvestasi baik investasi langsung maupun tidak langsung semakin meningkat. Peningkatan pendapatan ini juga dapat memicu perputaran modal yang cepat yang dilakukan oleh pelaku usaha atau perbankan yang menyalurkan pinjaman baik untuk konsumsi maupun untuk modal kerja.

Penyaluran kredit oleh perbankan dapat memicu semakin tingginya produksi dan hasil pengolahan.

Dengan adanya penawaran kredit dari perbankan dan dengan bunga yang terjangkau dapat meningkatkan produksi karena dengan pinjaman modal para pelaku usaha dapat memperluas lahan produksi begitu juga pada pinjaman modal untuk sektor industry. Dengan mendapat pinjaman modal dari perbankan maupun lembaga keuangan lainnya pelaku usaha dapat meningkatkan produksi dengan memperbaharui tekhnologi yang digunakan, menambah tenaga kerja ataupun keperluan modal lainnya untuk meningktakan produksi hasil industri. Hal ini lah yang pada akhirnya meningkatkan ekspor Indonesia.

\section{KESIMPULAN}

Berdasarkan hasil regresi dengan menggunakan E-views7 dengan uji unit root, kointegrasi dan uji kausalitas Granger dapat disimpulkan terjadi hubungan satu arah antara PDB (Produk Domestik Bruto) dan ekspor yaitu PDB mempengaruhi ekspor karena nilai Fstatistik (5.33078) lebih besar dari pada $F$ tabel bernilai (4.03) dan nilai probability lebih kecil dari 0.005 yaitu sebesar 0.0038 ini berarti Null Hypotesis: GDP does not Granger Cause Export ditolak artinya PDB memengaruhi Ekspor di Indonesia dan terjadi hubungan jangka panjang antara kedua variabel karena nilai pada none (terdapat keseimbangan jangka panjang satu arah) $37.42216>15.494471$ dan at most (terdapat keseimbangan jangka panjang dua arah) $8.958205>3.841466$ dan data telah stasioner pada derajat integrasi satu atau I (1) pada selang kepercayaan $95 \%$. 


\section{REFERENSI}

[1] T. soufan and S. A. Ruba Abu shihab, "The Causal Relationship between Exports and Economic Growth in Jordan," Int. J. Econ. Sci. ..., vol. 5, no. 3, pp. 302-308, 2004.

[2] Andre C. Jordaan and and joel hinaunye Eita, "Export And Economic Growth In Namibia: A Granger Causality Analysis," South African J. Econ., vol. 75, no. 3, pp. 540-547, 2007.

[3] P. D. Mukherji Ronit, "The relationship between the growth of exports and growth of gross domestic product of India Mukherji," Int. J. Bus. Econ. Res., vol. 3, no. 3, p. 135, 2014.

[4] Bakari, "The Relationship among Exports, Imports and Economic Growth in Turkey," J. Econ. Sustain. Dev., no. 76044, pp. 0-19, 2017.

[5] M. Albiman $\mathrm{Md}$ and S. NN, "The Relationship among Export, Import, Capital Formation and Economic Growth in Malaysia," J. Glob. Econ., vol. 4, no. 2, pp. 2-7, 2016.

[6] F. D. Raswatie, "Hubungan Ekspor Produk Domestik Bruto (PDB) di Sektor Pertanian Indonesia," J. Agric. Resour. Environ. Econ., vol. 1, no. 1, pp. 28-42, 2014.

[7] S. Dutta, Probal and Bose, "Trade and Economic Growth in Germany," Econ. Policy, no. 2116, pp. 0-33, 2011.

[8] M. Mehrara and B. A. Firouzjaee, "Granger Causality Relationship between Export Growth and GDP Growth in Developing Countries: Panel Cointegration Approach," Int. J. Humanit. Soc. Sci., vol. 1, no. 16, pp. 223-231, 2011.

[9] S. Bakari and M. Mabrouki, "Impact of Exports and Imports on Economic Growth: New Evidence From Panama," J. Smart Econ. Growth, vol. 2, no. 1, pp. 67-79, 2017.
[10] K. S. and S. Sirait, "Effective BUMDes Management Strategies to Improve Village Economy in Naga Dolok Village, Simalungun Regency," Jurnal Mantik, vol. 4, no. 3, pp. 2218-2224, 2020.

[11] S. Sirait and K. Sinaga, "Analisis Strategi Pemasaran Terhadap Minat Nasabah Pada Perbankan Di Pematangsiantar," J. Ekon. dan Bisnis, vol. 3, no. 1, p. 248, 2020. 